\title{
Identifikasi Kualitas Beras Putih (Oryza sativa L.) Berdasarkan Kandungan Amilosa dan Amilopektin di Pasar Tradisional dan "Selepan" Kota Salatiga
}

\author{
Andriyani Rosita Sari ${ }^{*}$, Yohanes Martono², \& Ferdy Semuel Rondonuwu ${ }^{3}$ \\ 1,2Program Studi Kimia, Fakultas Sains dan Matematika, Universitas Kristen Satya Wacana \\ ${ }^{3}$ Program Studi Pendidikan Fisika, Fakultas Sains dan Matematika, Universitas Kristen Satya Wacana \\ ${ }^{2,3}$ Pusat Studi Aplikasi Infra-merah Dekat, Fakultas Sains dan Matematika, Universitas Kristen Satya Wacana \\ *Email : andrianirositasari@gmail.com
}

\begin{abstract}
Abstrak
Kualitas beras dapat dipengaruhi dari karakteristik kimiawi yang berbeda seperti kandungan amilosa dan atau amilopektin. Penelitian ini bertujuan untuk mengindentifikasi kualitas beras berdasarkan kandungan amilosa dan amilopektin pada berbagai varietas beras putih di pasar tradisional dan "selepan" daerah Kota Salatiga dan sekitarnya. Metode yang digunakan yaitu spektrofotometri UV-Vis pada panjang gelombang 530nm dan 630nm. Perbedaan rata-rata kandungan amilosa dan amilopektin antar varietas diuji menggunakan RAL dengan metode ANOVA satu arah dengan selang kepercayaan 95\%. Berdasarkan data yang diperoleh, kandungan amilosa dalam varietas IR64 (27,40-28,64\%), GH (26,39-28,48\%), MW (22,84-27,52\%;), PW (18,94-23,57\%), dan Umbul (27,21-28,02\%). Kandungan amilopektin pada varietas IR64 (59,57-60,06\%), GH (56,72-63,52\%), MW (53,64$61,63 \%)$, PW (54,67-62,43\%), dan Umbul (53,41-57,98\%). Berdasarkan uji ANOVA, kandungan amilosa pada varietas PW "selepan" kandungan amilosa paling rendah dibandingkan dengan di pasar tradisional dan varietas lainnya. Kandungan amilosa yang rendah akan meningkatkan kriteria kepulenan nasinya. Kandungan amilopektin tertinggi terdapat pada varietas beras GH "selepan".
\end{abstract}

Kata kunci: Kota Salatiga, Kualitas beras putih, Amilopektin, Amilosa.

\section{PENDAHULUAN}

Padi (Oryza sativa L.) memiliki bentuk dan warna yang beragam, baik tanaman maupun berasnya. Beras merupakan makanan sumber energi yang memiliki kandungan karbohidrat tinggi sehingga dijadikan makanan pokok orang Indonesia dan beberapa negara lain (Adnan, Suhartini, \& Kusbiantoro, 2013). Di Indonesia, terdapat beras dengan bermacam-macam warna antara lain beras putih (Oryza sativa L.), beras hitam (Oryza sativa L. indica) dan beras merah (Oryza nivara). Sampai saat ini, beras berwarna putih masih mendapat perthatian lebih dibandingkan beras dengan warna lainnya (Suliartini, Sadimantara, Wijayanto, \& Muhidin, 2011).

(a)

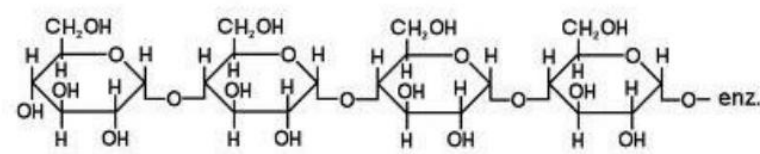

(b)

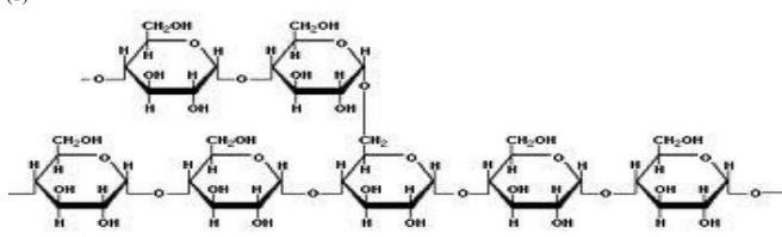

Gambar 1. Struktur kimia a) amilosa dan b) amilopektin (Ulyarti, 1997)

Di dalam beras putih terkandung $85-95 \%$ pati, 2-2,5\% pentosan, dan 0,6-1,1 gula. Rangka struktur pati terdiri atas dua komponen utama yaitu amilosa dan amilopektin yang tersusun oleh rangkaian unit-unit (glukosa) yang saling berikatan (Gambar 1). Amilosa merupakan polisakarida yang terdiri dari glukosa rantai linier. Bukti kelinieran amilosa ditunjukkan dengan hidrolisis enzim $\beta$ amilase yang mampu mengubah amilosa secara kuantitatif menjadi maltosa. Sedangkan amilopektin adalah molekul hasil polimerisasi unit-unit glukosa anhidrous melalui ikatan $\alpha-1,4$ dan ikatan cabang a-1,6 pada setiap 20-26 unit monomer. Struktur cabang amilpektin merupakan salah satu hasil 
mekanisme enzim yang memecah rantai linier yang panjang. Hasil pecahan berupa rantai-rantai pendek dengan 25 unit glukosa yang kemudian bergabung membentuk struktur berantai banyak (Ulyarti, 1997). Amilosa dan amilopektin berpengaruh pada sifat pati yang dihasilkan. Sifat fungsional pati juga dipengaruhi oleh varietas, kondisi alam, dan tempat tanaman tersebut berasal (Nisah, 2017).

Sifat-sifat fisikokimia beras sangat menentukan mutu tanak (cooking quality) dan mutu rasa (eating quality) nasi yang dihasilkan. Lebih khusus lagi, mutu secara kimiawi ditentukan oleh kandungan amilosa dan amilopektin. Kandungan amilosa berkorelasi positif dengan aroma, jumlah penyerapan air, pengembangan volume nasi selama pemasakan, dan tetap menggumpal setelah dingin serta berkorelasi negatif terhadap nilai taste pane/ dari kelekatan (cohesiveness), kelunakan (tenderness), warna dan kilap (Dianti, 2010; Soenardjo, Damardjati, \& Syam, 1991; Suliartini, Sadimantara, Wijayanto, \& Muhidin, 2011). Berdasarkan kandungan amilosa, beras diklasifikasikan menjadi ketan atau beras beramilosa rendah (8-20\%), sedang (21-25\%), dan tinggi (>25\%) (Kumar \& Kush, 1986).

Sifat-sifat tersebut di belakang berkorelasi dengan kandungan amilopektin (Suliartini et al., 2011). Amilopektin merupakan komponen yang berperan penting dalam proses gelatinisasi. Tingginya kadar amilosa dapat menurunkan kemampuan pati untuk mengalami gelatinisasi (Nisah, 2017). Konsistensi gel beras merupakan karakter yang akan menunjukkan tekstur nasi setelah dingin (Wibowo, Indrasari, \& Jumali, 2009).

Rasio antara kandungan amilosa dengan kandungan amilopektin merupakan faktor yang sangat penting dalam menentukan mutu warna dan tekstur nasi, baik dalam keadaan masih hangat maupun sudah mendingin hingga suhu kamar (Suliartini et al., 2011). Selain itu semakin panjang rantai amilopektin dan makin tinggi kandungan amilosa juga akan memberikan kondisi yang sesuai bagi terjadinya inter atau intra-interaksi antara molekul pati dengan komponen lain, seperti protein dan lemak sehingga mempengaruhi besar kandungan komponen lainnya. Keadaan sebaliknya untuk struktur beras yang memiliki rantai amilopektin pendek (Wibowo et al., 2009).

Karakter beras penting diketahui untuk proses perakitan varietas baru, penyimpanan, penanganan, dan pengolahan lebih lanjut. Pada industri beras yang modern, identifikasi sifat fisik beras bermanfaat dalam aspek pengendalian mutu (quality control) dan jaminan mutu (quality assurance). Konsumen tertentu menginginkan jaminan mutu beras yang dikonsumsinya (Adnan, Suhartini, \& Kusbiantoro, 2013).

Ditinjau dari sisi penerapan standar mutu beras, karakter mutu yang paling disukai konsumen dapat diartikan sebagai identifikasi status pemahaman dan penerimaan standar atau kelas mutu beras yang ada. Preferensi konsumen terhadap beras pada kelas mutu tertentu dipengaruhi oleh banyak faktor, antara lain penampilan fisik beras, kepulenan nasi, budaya, dan tingkat sosial-ekonomi konsumen. Konsumen mengapresiasi kesesuaian karakter beras yang disukai dengan cara membayar insentif harga untuk tingkat mutu beras tertentu (Wibowo, Indrasari, \& Jumali, 2009).

Hasil identifikasi dan pengujian mutu beras ini dapat digunakan sebagai bahan kajian pemilihan dan pengembangan varietas padi dengan karakteristik mutu beras yang terdapat di wilayah setempat. Sehingga penelitian ini bertujuan untuk mengindentifikasi kualitas beras berdasarkan kadar amilosa dan amilopektin pada berbagai varietas beras giling di pasar tradisional dan "selepan" di daerah Kota Salatiga dan sekitarnya.

\section{METODE/EKSPERIMEN}

Penelitian ini dilakukan pada tahun 2018 di Laboratorium Kimia Universitas Kristen Satya Wacana (UKSW) Salatiga. Sampel yang digunakan sebanyak 44 macam terdiri atas lima jenis varietas beras putih yaitu IR64, GH, Mentik Wangi, Pandan Wangi, dan Umbul yang diambil dari 7 pasar tradisional dan 6 unit penggilingan padi atau "selepan" di daerah Kota Salatiga dan Kabupaten Semarang. Pada saat pembelian sampel, pedagang selepan diminta untuk memberikan stok beras terbaru sedangkan di pasar tradisional menggunakan stok beras yang tersedia di bagian depan toko tanpa mengetahui umur beras yang dijual.

Bahan yang digunakan yaitu amilosa standart, amilopektin standart, Natrium Hirdoksida $(\mathrm{NaOH})$, Asam Klorida $(\mathrm{HCl})$, lodine $\left(\mathrm{I}_{2}\right)$, Kalium lodida $(\mathrm{KI})$, dan trichloroacetic acid $(\mathrm{TCA})$ semua bahan mempunyai derajar pro analisis dari Merck, Germany. Akuades didapatkan dari Laboratorium Kimia UKSW Salatiga, Indonesia.

Alat dalam penelitian ini adalah blender (Philips), ayakan 60 mesh, neraca analitik (OHAUS PA214) dengan ketelitian 0,1 mg, spektrofotometer Ultraviolet-Visible/UV-Vis (Optizen UV 2120).

\section{Persiapan Sampel}

Sampel beras dihaluskan menggunakan blender dan diayak sehingga menghasilkan beras 
berukuran 60 mesh yang dapat digunakan untuk pengujian selanjutnya.

\section{Rasio Amilosa dan Amilopektin}

Pengukuran Sampel Kadar Amilosa (Christianty, Martono, \& Riyanto, 2018)

Sampel ditimbang sebanyak 20,0 mg dan dilarutkan ke dalam $5 \mathrm{ml} N a O H 1 \mathrm{M}$ dan $5 \mathrm{ml}$ akuades. Larutan sampel diambil sebanyak $1 \mathrm{ml}$ dan ditambahkan $5 \mathrm{ml} \mathrm{HCl} 1 \mathrm{M}$ lalu digenapkan dengan akuades hingga volume menjadi $50 \mathrm{ml}$. Konsentrasi larutan baku amilosa untuk kurva baku yaitu antara 4-48 $\mu \mathrm{g} / \mathrm{mL}$. Larutan sampel diambil $5 \mathrm{ml}$, lalu ditambahkan dengan $2 \mathrm{ml}$ larutan TCA dan $2 \mathrm{ml}$ larutan reagen $\mathrm{I}_{2}-\mathrm{KI}$. Absorbansi larutan diukur menggunakan spektrofotometer UV-Vis pada panjang gelombang $630 \mathrm{~nm}$. Konsentrasi amilosa ditetapkan berdasarkan kurva baku standart amilosa sebagai persen (\%).

Pengukuran Sampel Kadar Amilopektin (Handayani, Riyanto, \& Martono, 2016)

Sampel ditimbang sebanyak 20,0 mg dan dilarutkan ke dalam $5 \mathrm{ml} \mathrm{NaOH} 1 \mathrm{M}$ dan $5 \mathrm{ml}$ akuades. Larutan sampel diambil sebanyak $1 \mathrm{ml}$ dan ditambahkan $5 \mathrm{ml} \mathrm{HCl} 1 \mathrm{M}$ lalu digenapkan dengan akuades hingga volume menjadi $50 \mathrm{ml}$. Konsentrasi larutan baku amilosa untuk kurva baku yaitu antara 5,0 10-3-5,0 $\quad 10^{-2} \mu \mathrm{g} / \mathrm{mL}$. Larutan sampel diambil $5 \mathrm{ml}$, lalu ditambahkan dengan $2 \mathrm{ml}$ larutan TCA dan $2 \mathrm{ml}$ larutan reagen $\mathrm{I}_{2}-\mathrm{Kl}$. Absorbansi larutan diukur menggunakan spektrofotometer UV-Vis pada panjang gelombang $530 \mathrm{~nm}$. Konsentrasi amilopektin ditetapkan berdasarkan kurva baku standart amilopektin sebagai persen (\%).

\section{Analisis Data}

Data penelitian dianalisis menggunakan Rancangan Acak Lengkap RAL) dengan metode Analisis Variansi (ANOVA) satu arah dengan selang kepercayaan 95\%.

\section{HASIL DAN PEMBAHASAN}

\section{Hasil}

Tabel 1. Klasifikasi Kandungan Amilosa Beras Putih

\begin{tabular}{cccc}
\hline $\begin{array}{c}\text { Varietas } \\
\text { Beras }\end{array}$ & Asal & $\begin{array}{c}\bar{x} \text { Kandungan Amilosa } \\
(\%)\end{array}$ & Klasifikasi $^{*}$ \\
\hline \multirow{2}{*}{ IR64 } & Selepan & 28,64 & Tinggi \\
& Pasar & 27,40 & Tinggi \\
\hline \multirow{2}{*}{ GH } & Selepan & 28,48 & Tinggi \\
& Pasar & 26,39 & Tinggi \\
\hline Mentik & Selepan & 22,84 & Sedang \\
Wangi & Pasar & 27,52 & Tinggi \\
\hline Pandan & Selepan & 18,94 & Rendah \\
Wangi & Pasar & 23,57 & Sedang \\
\hline \multirow{2}{*}{ Umbul } & Selepan & 27,21 & Tinggi \\
& Pasar & 28,02 & Tinggi \\
\hline
\end{tabular}

"Klasifikasi dilakukan berdasarkan kadar amilosa rendah <20\%, sedang antara $20-25 \%$, dan tinggi $>25 \%$ (Kumar \& Kush, 1986).

Tabel 2. Hasil Uji ANOVA pada Kandungan Amilosa Beras Putih

\begin{tabular}{lllllll}
\hline \multicolumn{1}{c}{ Faktor } & N & Mean & \multicolumn{2}{c}{ Kelompok } \\
\hline Kadar Amilosa IR64 Selepan & 3 & 28,64 & A & & \\
Kadar Amilosa GH Selepan & 2 & 28,48 & A & & \\
Kadar Amilosa Umbul Pasar & 3 & 28,02 & A & & \\
Kadar Amilosa Mentik Pasar & 3 & 27,51 & A & & \\
Kadar Amilosa IR64 Pasar & 3 & 27,40 & A & & \\
Kadar Amilosa Umbul Selepan & 2 & 27,20 & A & & & \\
Kadar Amilosa GH Pasar & 3 & 26,38 & A & B & & \\
Kadar Amilosa Pandan W Pasar & 3 & 23,57 & & B & C & \\
Kadar Amilosa Mentik Selepan & 3 & 22,83 & & & C & \\
Kadar Amilosa Pandan W Selepan & 3 & 18,94 & & & & D \\
\hline
\end{tabular}

Rata-rata yang tidak menujukkan huruf yang sama mempunyai arti berbeda nyata. 
Tabel 3. Klasifikasi Kadar Amilopektin Beras Putih

\begin{tabular}{cccc}
\hline Varietas Beras & Asal & $\begin{array}{c}\bar{x} \text { Kandungan } \\
\text { Amilopektin (\%) }\end{array}$ & Klasifikasi $^{*}$ \\
\hline \multirow{2}{*}{ IR64 } & Selepan & 59,58 & Sedang \\
& Pasar Tradisional & 60,61 & Sedang \\
\hline \multirow{2}{*}{ GH } & Selepan & 63,52 & Sedang \\
& Pasar Tradisional & 56,72 & Sedang \\
\hline \multirow{2}{*}{ Mantik Wangi } & Selepan & 53,64 & Sedang \\
& Pasar Tradisional & 61,63 & Sedang \\
\multirow{2}{*}{ Pandan Wangi } & Selepan & 54,67 & Sedang \\
& Pasar Tradisional & 62,43 & Sedang \\
\hline \multirow{2}{*}{ Umbul } & Selepan & 53,41 & Sedang \\
& Pasar Tradisional & 57,98 & Sedang \\
\hline
\end{tabular}

*Klasifikasi diusulkan berdasarkan kadar amilopektin rendah $<50 \%$. sedang antara $50-65 \%$. tinggi $>65 \%$.

Tabel 4. Hasil Uji ANOVA pada Kandungan Amilopektin Beras Putih

\begin{tabular}{lllllll}
\hline \multicolumn{1}{c}{ Faktor } & N & Mean & \multicolumn{1}{c}{ Kelompok } \\
\hline Kadar Amilopektin GH Selepan & 2 & 63,52 & A & & \\
Kadar Amilopektin PW Pasar & 3 & 62,43 & A & B & & \\
Kadar Amilopektin Mentik Pasar & 3 & 61,63 & A & B & & \\
Kadar Amilopektin IR64 Pasar & 3 & 60,60 & A & B & & \\
Kadar Amilopektin IR64 Selepan & 3 & 59,57 & A & B & C & \\
Kadar Amilopekti Umbul Pasar & 3 & 57,98 & A & B & C & D \\
Kadar Amilopektin GH Pasar & 3 & 56,72 & & B & C & D \\
Kadar Amilopektin PW Selepan & 3 & 54,67 & & C & D \\
Kadar Amilopektin Mentik Selep & 3 & 53,64 & & & D \\
Kadar Amilopektin Umbul Selepan & 2 & 53,41 & & C & D \\
\hline tang tidak menujukkan huruf yang sama mempunyai arti berbeda nyata.
\end{tabular}

\section{Pembahasan}

Beras yang dijual di pasar tradisional dan "selepan" merupakan beras yang telah melalui beberapa proses penggilingan, mulai dari pengelupasan kulit dan lapisan lainnya hingga penyosohan. Proses penyosohan beras pecah kulit menghasilkan beras giling, dedak dan bekatul. Beras giling berwarna putih agak transparan karena hanya memiliki sedikit aleuron dan kandungan amilosa umumnya sekitar $20 \%$. Makin tinggi derajat penyosohan dilakukan makin putih warna beras giling yang dihasilkan, namun makin miskin zat-zat gizi (Dianti, 2010).

Mutu giling dan rupa beras lebih banyak ditentukan oleh teknik perlakuan teknologi lepas panen yaitu teknik pemanenan, pengeringan, penyimpanan, dan penggilingan. Sedangkan sifat mutu tanak lebih ditentukan oleh mutu genetik (sifat-sifat varietas) dan kondisi penanaman, seperti pemupukan, jenis tanah, dan iklim daripada perlakuan pasca panen. Di Indonesia, mutu tanak belum merupakan kriteria yang berlaku dalam penentuan mutu beras, tetapi di pasaran internasional khususnya Amerika Serikat mutu tanak merupakan salah satu persyaratan mutu beras, terutama dalam hubungannya dengan industri pengolahan beras. Mutu tanak dan rasa nasi terutama ditentukan oleh rasio antara kandungan amilosa dan amilopektin (Soenardjo, Damardjati, \& Syam, 1991).

Secara umum dapat dikatakan bahwa sifat-sifat nasi sangat dipengaruhi oleh kandungan amilosanya, semakin tinggi kandungan amilosa beras makin rendah tingkat kepulenan nasinya atau disebut pera. Dalam kriteria mutu rasa dikenal nasi pera yaitu nasi yang keras, kering setelah dingin, lebih mengembang dan tidak lekat satu sama lain. Selain itu ada nasi pulen yang cukup lunak walaupun sudah dingin, lengket walaupun tidak seperti ketan, antar biji lebih berlekatan satu sama lain, dan mengkilap (Soenardjo et al., 1991).

Hasil eksplorasi dan koleksi beberapa varietas beras putih dari pasar tradisional dan "selepan" di daerah Kota Salatiga dan sekitarnya telah dianalisis kadar amilosa dan dikelompokkan berdasarkan besarnya kandungan amilosa menjadi rendah, sedang, dan tinggi (Tabel 1). Beras varietas IR64, GH, dan Umbul baik di pasar maupun "selepan" mempunyai kandungan amilosa tinggi. Sedangkan pada varietas Mentik Wangi "selepan" dan Pandan Wangi mempunyai kandungan amilosa yang lebih rendah. Varietas Mentik Wangi pada unit "selepan" beramilosa sedang, varietas 
Pandan Wangi pada unit "selepan" beramilosa rendah, dan varietas Pandan Wangi di pasar sedang.

Berdasarkan uji ANOVA pada Tabel 2, kandungan amilosa pada varietas Pandan Wangi "selepan" kandungan amilosa paling rendah dibandingkan dengan di pasar tradisional dan varietas lainnya. Kandungan amilosa yang rendah akan meningkatkan kriteria kepulenan nasinya. Varietas Pandan Wangi "selepan" berbeda nyata dengan dengan di pasar tradisional dan varietas lainnya sehingga tekstur nasinya akan lebih pulen.

Perbedaan kandungan amilosa yang terjadi dalam satu varietas antara yang dijual di pasar dengan "selepan" dimungkinkan karena adanya perbedaan umur penyimpanan. Penyimpanan beras giling yang terlalu lama dapat menyebabkan naiknya kadar amilosa secara signifikan. Selain itu, beras Mentik Wangi dan Pandan Wangi merupakan beras dengan keterbatasan lahan produksi, umur tanam yang relatif lama, memiliki kekhasan aroma, dan rasa yang enak membuat beras ini termasuk dalam beras unggul dengan harga tinggi. Hal tersebut memicu para distributor untuk melakukang pengoplosan sehingga dapat menurunkan kualitas asli beras tersebut (Arkanti, 2007; Dianti, 2010). Selain itu kondisi alam dan tempat tanaman tersebut berasal juga dapat menyebabkan adanya kandungan amilosa yang bervariasi (Nisah, 2017).

Kandungan amilosa di dalam beras juga berpengaruh terhadap cooking characteristic yang lain, yaitu pengembangan volume dan penyerapan air nasi selama ditanak. Rasio pengembangan volume dan penyerapan air nasi semakin besar dengan semakin tingginya kadar amilosa. Amilosa merupakan polisakarida yang terdiri dari glukosa yang membentuk rantai linier dan memiliki kemampuan untuk membentuk ikatan hidrogen atau untuk mengalami retrogradasi. Retrogradasi merupakan proses terbentuknya jaringan mikrokristal dari molekul-molekul amilosa yang berikatan kembali satu sama lain atau dengan percabangan amilopektin di luar granula pati yang telah mengalami gelatinasi pada saat pasta telah dingin (Hernawan \& Meylani, 2016; Winarno, 1997).

Gelatinasi terjadi ketika suspensi pati dalam air dipanaskan yang menyebabkan pengembangan volume nasi diikuti oleh pembengkakan granula pati dan permukaan butir beras yang retak. Pembengkakan ini terjadi bila energi kinetik molekul-molekul air menjadi lebih kuat dari gaya tarik-menarik antar molekul pati didalam granula sehingga air dapat masuk ke dalam butur-butir pati. Mekanisme gelatinisasi pati terdiri dari tiga tahap yaitu yang pertama air terpenetrasi secara bolak balik ke dalam granula. Kemudian pada suhu $60-85^{\circ} \mathrm{C}$ granula akan mengembang dengan cepat dan akhirnya kehilangan sifat birefringence-nya. Terakhir jika temperatur terus naik maka molekul-molekul pati akan terdifusi dari granula (Winarno, 1997). Pada proses gelatinasi terjadi pengrusakan ikatan hidrogen intramolekuler. Ikatan hidrogen memiliki peranan untuk mempertahankan struktur intregitas granula (Richana \& Sunarti, 2004).

Amilosa memiliki gugus hidroksil dengan jumlahnya sangat banyak yang menyebabkan kemampuan menyerap airnya sangat besar. Hal inilah yang menyebabkan granula pati membengkak. Bila pati telah mendingin, energi kinetik tidak lagi cukup tinggi untuk melawan kecenderungan molekul-molekul amilosa untuk bersatu kembali (Hernawan \& Meylani, 2016; Ulyarti, 1997; Winarno, 1997). Semakin tinggi kadar amilosanya, daya serap airnya pun akan semakin tinggi sehingga pengembangan volume dari beras yang dimasak akan tinggi juga. Peningkatan kadar amilosa akan meningkatkan kapasitas granula pati dalam menyerap air dan pengembangan volume sebab amilosa mempunyai kapasitas yang lebih besar dalam mengikat hidrogen daripada amilopektin. Proporsi amilosa dan struktur amilopektin memiliki peranan penting pada kecepatan dan derajat retrograsi pati (Lin, Singh, Chang, \& Chang, 2011).

Peran amilopektin dalam sifat fungsional pati sedikit sulit untuk ditentukan sehingga dalam banyak penelitian karakterisasi pati dari beras hanya dari kandungan amilosanya saja. Amilopektin memiliki kecenderungan untuk membentuk kumpulan tidak larut air yang membuat teksturnya lebih pekat dan lengket (Masniawati, Johannes, Latunra, \& Paelongan, 2012). Rantai cabang lebih panjang pada amilopektin memiliki kecendrungan yang kuat untuk membentuk gel. Amilopektin merupakan molekul yang bercabang, sehingga molekul air yang terikat padanya tidak mudah lepas. Hal ini menyebabkan stabilnya produk selama penyimpanan.

Penelitian kandungan amilopektin sering kali dilakukan dengan metode by different dimana kandungan amilopektin didapatkan dari selisih total karbohodrat dengan kandungan amilosa. Sehingga asumsi tingginya kandungan amilosa akan menyebabkan kandungan amilopektin rendah dan sebaliknya. Berdasarkan hasil penelitian penentuan kandungan amilopektin menggunakan metode spektrofotometri UV-Vis pada Tabel 3, semua beras mempunyai kandungan amilopektin sedang. Kandungan amilopektin tertinggi terdapat pada varietas beras $\mathrm{GH}$ "selepan" sebesar $63,52 \%$. Berdasarkan Tabel 4 meskipun kandungan amilopektin pada semua varietas termasuk dalam kelompok sedang namun mempunyai perbedaan yang berbeda nyata. Misalnya pada GH "selepan" berbeda nyata dengan beras GH "pasar", Pandan Wangi, Mentik Wangi, dan Umbul "selepan".

Perbedaan tekstur antar varietas terkait erat dengan perbedaan kandungan amilosa, 
perbandingan rantai panjang dan pendek molekul amilopektin, serta struktur granula pati. Beras dengan kadar amilosa tinggi dan memiliki amilopektin rantai panjang cenderung mempunyai tekstur nasi yang keras. Sebaliknya, beras yang memiliki kadar amilosa rendah dan amilopektin rantai pendek cenderung mempunyai tekstur nasi yang lunak (Wibowo, Indrasari, \& Jumali, 2009).

\section{PENUTUP}

Berdasarkan uji ANOVA, kandungan amilosa pada varietas Pandan Wangi "selepan" kandungan amilosa paling rendah dibandingkan dengan di pasar tradisional dan varietas lainnya. Kandungan amilosa yang rendah akan meningkatkan kriteria kepulenan nasinya. Kandungan amilopektin tertinggi terdapat pada varietas beras GH "selepan". Perlu dilakukan penelitian lebih lanjut mengenai hubungan antara kandungan amilopektin dengan masa penyimpanan dan konsistensi gel untuk mendukung karakterisasi mutu tanak nasi.

\section{DAFTAR PUSTAKA}

Adnan, Suhartini, \& Kusbiantoro, B. (2013). Identifikasi Varietas Berdasarkan Warna dan Tekstur Permukaan Beras Menggunakan Pengolahan Citra Digital dan Jaringan Syaraf Tiruan. Penelitian Pertanian Tanaman Pangan, Vol 32 No(July).

Arkanti, L. W. (2007). Karakterisasi Sifat Fisiko-Kimia dan Sensori Beras Pandan Wangi, Morneng, dan BTN. Institut Pertanian Bogor.

Christianty, M. A., Martono, Y., \& Riyanto, C. A. (2018). Validasi Metode Analisis Amilosa Secara Spektrofotometri Ultraviolet-Visible (UV-Vis) dalam Singkong, 157-162.

Dianti, R. W. (2010). Kajian Karakteristik Fisikokimia dan Sensori Beras Organik Mentik susu dan IR64; Pecah Kulit dan Giling Selama Penyimpanan. Universitas Sebelas Maret Surakarta.

Handayani, C., Riyanto, C. A., \& Martono, Y. (2016). Pengaruh Fortifikasi Tepung Pisang Uter (Musa paradisiaca Lin) Var Uter dan Substitusi Terigu dalam Mocaf Terasetilasi Ditinjau dari Kandungan Amilosa dan Amilopektin. In SN-KPK IX (pp. 187-195).

Hernawan, E., \& Meylani, V. (2016). Analisis Karakteristik Fisikokimia Beras Putih, Beras Merah, dan Beras Hitam (Oryza sativa L., Oryza nivara dan Oryza sativa L. indica). Jurnal Kesehatan Bakti Tunas Husada, 15 Nomor 1, 79-91.

Kumar, I., \& Kush, G. S. (1986). Gene Dosage Effect of Amylose Content in Rice Endosperm. Japan Journal Genetics, 61, 559-568.

Lin, J., Singh, H., Chang, Y., \& Chang, Y. (2011). Factor analysis of the functional properties of rice flours from mutant genotypes. Food Chemistry, 126(3), 1108-1114. https://doi.org/10.1016/j.foodchem.2010.11.140

Masniawati, A., Johannes, E., Latunra, A. I., \& Paelongan, N. (2012). Karakterisasi Sifat Fisikokimia Beras Merah Pada Beberapa Sentra Produksi Beras di Sulawesi Selatan.

Nisah, K. (2017). Studi Pengaruh Kandungan Amilosa dan Amilopektin Umbi-Umbian Terhadap Karakteristik Fisik Plastik Biodegredable dengan Plastizicer Gliserol. Jurnal Biotik, 5 No. 2(ISSN: 2337-9812), 106-113.

Richana, N., \& Sunarti, T. C. (2004). Karakterisasi Sifat Fisikokimia Tepung Umbi dan Tepung Pati dari Umbi Ganyong, Suweg, Ubi Kelapa, dan Gembili. J.Pascapanen, 1(1), 29-37.

Soenardjo, E., Damardjati, D., \& Syam, M. (1991). Padi Buku 3. Badan Penelitian dan Pengembangan Pertanian Pusat Penelitian Tanaman Pangan Bogor.

Suliartini, N. W. S., Sadimantara, G. R., Wijayanto, T., \& Muhidin. (2011). Pengujian Kadar Antosianin Padi Gogo Beras Merah Hasil Koleksi Plasma Nutfah Sulawesi Tenggara. Crop Agro, 4(2), 4348. 
30 | Titian Ilmu: Jurnal IImiah Multi Sciences Vol. 12 No. 1, Januari 2020

Ulyarti. (1997). Mempelajari Sifat-sifat Amilografi pada Amilosa, Amilopektin, dan Campurannya. Institut Pertanian Bogor.

Wibowo, P., Indrasari, S. D., \& Jumali. (2009). Identifikasi Karakteristik dan Mutu Beras di Jawa Barat. Penelitian Pertanian Tanaman Pangan, VOL. 28 NO, 43-49.

Winarno, F. (1997). Kimia Pangan dan Gizi. Jakarta: Gramedia Pustaka Utama. 